Wildenthal, Lora, Zimmerer, Juergen, Berman, Russell A., Rüger, Jan, Naranch, Bradley, Kundrus, Birthe and Maiken Umbach. The German Colonial Imagination. German History 26, no. 2 (2008): 251-271. doi: 10.1093/gerhis/ghn005.

\title{
The German Colonial Imagination
}

\author{
Lora Wildenthal, Rice \\ Juergen Zimmerer, Sheffield \\ Russell A. Berman, Stanford \\ Jan Rüger, Birkbeck, London \\ Bradley Naranch, Loyola College, Maryland \\ Birthe Kundrus, Hamburger Institut für Sozialforschung \\ Maiken Umbach, Manchester
}

German History continues its series of virtual round-table discussions with this forum on the German colonial imagination, a topic very much at the centre of current historical controversy. By European standards, the period of formal German colonialism was extremely brief. Yet work inspired by cultural and literary studies has suggested that a 'colonial imagination' was much more deeply rooted in German society than the brevity of the political experiment suggests. This in turn has led to a reassessment of colonialism's role, for example, in the evolution of German liberalism and nationalism. Colonial historians have not always welcomed these new developments, some arguing that the culturalist perspective tends to be Eurocentric, and accords too little agency to the colonized. Alongside methodological controversies, the longue durée of the colonial legacy has come under renewed scrutiny. In particular, a more sustained engagement with Germany's colonial history, real and imagined, has inspired new work on the origins of National Socialism. Like most claims about the long-term origins of historical phenomena, this has been criticized as unduly teleological by some, and insufficiently aware of the transnational dynamic of colonial mindsets by others. Relatedly, it has been suggested that, rather than finecombing German cultural history for traces of colonial attitudes, we should use such sources to try to explain Germany's remarkable reluctance to join the scramble for colonial possessions. German History has invited six distinguished experts in the field to comment on the state of the debate. They are Lora Wildenthal (Rice), Juergen Zimmerer (Sheffield), Russell A. Berman (Stanford), Jan Rüger (Birkbeck, London), Bradley Naranch (Loyola College, Maryland), and Birthe Kundrus (Hamburger Institut für Sozialforschung). Maiken Umbach (Manchester, and joint editor of German History) formulated the questions. 


\section{Recent years have seen an explosion of new work on the German colonial imagination. Much of this takes its cue from the pioneering studies by the late Susanne Zantop, and borrows heavily from history's neighbouring disciplines, notably the history of literature. Is this a case where the shift to cultural history has made an important strand of German national identity visible that was previously obscured?}

Naranch: Zantop's innovative research helped to establish a bridgehead for younger scholars to cross the disciplinary divide separating cultural history and cultural studies. The result has been the emergence in the past decade of a vibrant and increasingly visible German colonial studies movement. Both sides have benefited from these exchanges. Historians have gained a more nuanced understanding of the ambivalent ways that textual and visual sources concerning nonWestern peoples and cultures have influenced the construction of German national identity. It is difficult to understand the recent 'visual turn' in German colonial history without the influence of cultural and media studies. Cultural studies scholars have gained a greater appreciation for the [End Page 251] variations in the German colonial experience across time and space, especially the disparity between the ambitious sweep of German colonial fantasies and the meagre set of political, military, and economic resources that were available to transform them into reality. It would be going too far, however, to claim that these intellectual exchanges have rendered visible a strand of German nationalism that was previously obscured. Many historians have long acknowledged the importance of race, gender and sexuality as building blocks of German national identity. This was a result of the 'cultural turn' in the 1980s, not the 'colonial turn' of the mid-1990s. What German colonial studies has accomplished is the construction of an impressive array of interdisciplinary partnerships between new generations of historians and cultural studies scholars, which selfless and dedicated individuals such as Zantop invested so much time and energy in fostering.

Wildenthal: Yes, definitely this is a case where cultural history has brought something forward that other approaches neglected. Until Zantop and others persuaded people to think more flexibly about the forms and impact that colonial thinking could have, historians' main response to the German colonial empire seems to have been 'it was so brief, it can't have been very important to German history.' It has been necessary to explore the worlds of imagination and fantasy to get past that approach to defining and judging importance. Whether the number of years Germany ruled a colony is the best metric of 'importance' depends entirely on what you are investigating. The overall historiography of German colonialism is larger and older than some may realize, but was focused more on political and diplomatic themes than social and cultural ones and had therefore receded in prominence in recent years. Older texts offering excellent sources and cultural analysis do exist, such as Mack Walker's Germany and the Emigration (1964) and Klaus Hildebrand's passages in Vom Reich zum Weltreich (1969) on colonial themes in everyday material culture in the Weimar Republic. Entirely new topics become visible with this cultural approach, such as the history of the forgetting of colonial empire among Germans after 1945 and their sense of the bizarre when they encounter its traces - as broached in Brigitta SchmidtLauber's ethnographies of German Namibians (1993 and 1998).

Kundrus: 'Obscured' is too strong a term. Historians writing on German national identity before the most recent studies on colonialism appeared have already provided answers to key questions of national identity; one example is Joachim Radkau's 1998 Das Zeitalter der Nervosität: 
Deutschland zwischen Bismarck und Hitler. Yet a majority of German historians have overlooked the work done in cultural history, which has, for example, explored the educated classes' constant vacillation between arrogance and self-doubt, the ambivalence of fractured selfconfidence and unswerving confidence in the future, the upsurge of hierarchical and raciallydefined models of social order. This neglect has led them to underestimate the significance of the colonies for these complex affective states - as a kind of picture puzzle reflection of national identities. Recent research on colonialism accentuates more clearly the need to span the caesuras of 1884, 1918, and 1945, since Zantop's work, which addressed colonial fantasies before 1871, highlights the need to examine not only the short phase of colonial rule in the Wilhelmine period, but to consider how colonialism influenced German history throughout the modern era. What is the significance of this unique German constellation - a fleeting national imperial phase in the long global era of imperialism - in the context of the country's history? What tensions result from a transient 'real' imperial history and a much longer and more intensive history of imperial intentions? [End Page 252]

Zimmerer: It is certainly true that the colonial imagination has been neglected in German studies until very recently, at least with regards to the imagination as documented in literature or art. However, the German colonial imagination must not be reduced to published texts alone. One should also look at the practitioners of German colonialism, who had dreams and imaginations as well - and even acted on them! If one takes them seriously, then the question tells only half the truth. Yes, mainstream German studies have ignored German colonial experience and imagination for a very long time. But this applies only to those disciplines for which German national history, literature and culture was the central focus. Alongside these, there were histories of colonialism or regional histories (area studies) of regions that had formed part of the German colonial empire. The latter owe more to anthropology and ethnology than to literary studies. That they are ignored in the question reflects the neglect that global topics still face in the study of Germany. Only when the significance for German national history had been proven did the mainstream disciplines start to show interest. The history of literature, with its emphasis on the imaginary, ideas and myth, is certainly a key discipline to understanding the attraction of colonialism for the German Bildungsbürgertum. It shows how foreign tradition and cultures were appropriated in Europe. And since it is a key assumption of postcolonial theory that knowledge and power are interrelated and that control of the epistemological systems is a precondition for political dominance and control, images are central for colonialism. But analysing and explaining the dreams of the colonizers is not sufficient for understanding colonialism. It tells us nothing, for example, about the colonized, let alone telling the story from their perspective. We should be very cautious about taking literary representations of colonialism as a source for day-to-day reality.

Berman: It is hardly surprising that this shift toward questions of the imagination (the colonial imagination) resulted from intellectual borrowings from the field of literature. Literature is about imagination, about fictional worlds, and the study of literature is, ultimately, a complex inquiry into the objects of imagination. As a field, history carries a much heavier empiricist ballast. Clever postmodernists may point out how the border between the two may be blurred: don't authors write memoirs with documentary validity? Don't historians construct 'narratives'? These platitudes are undeniable, but there are persistent differences between the disciplines, which also means that - in a context of interdisciplinary borrowing - it is no surprise that literary studies 
pull history toward the imagination. Yet another distinction is at stake in the term 'cultural history' and the amphibious slipperiness of 'culture'. Zantop's treatment is primarily literary: her argument is that literary authors, writing in German, participated in European (really all European?) discourses of colonialism prior to the emergence of a genuine colonial agenda in Germany: hence, a fantasy. Yet the 'culture' in 'cultural history' often carries a much stronger anthropological or ethnographic inflection à la Geertz, presumably to lend it the pseudoobjectivity of the social sciences. Zantop, to her credit, did not go down that route. The reception of her work in the field of history is an example of the impact of literary studies, not of the cultural anthropology with which literary culture is often confused. Indeed, Zantop's work, which is so emphatically critical of the European colonial enterprise (in its fantasies and in its practices), draws on a deeply moral judgement which is incompatible with the confused cultural relativism of cultural anthropology. [End Page 253]

Rüger: The idea of a 'colonialism without colonies' has produced impressive research, reminding us about important continuities in German nationalist and imperialist thinking. Ideas of the nation, as they were formulated in the course of the nineteenth century, were repeatedly linked to the evocation of 'overseas'. National liberalism was never divorced from thinking about colonies. Many of the leading figures involved in the revolution of 1848, for example, thought of a united Germany as a nation that would go beyond its boundaries and play an important role overseas. The historiographical impulse associated with the late Susanne Zantop has thus resulted in a heightened awareness of the ways in which 'the nation' was linked to ideas of empire long before such an empire became reality. It seems to me that this strand of research now needs to be connected to the historiography dealing with other realms of identity politics. How, in particular, does 'the' imperialist imagination relate to the local and regional contexts that historians of modern Germany have been so interested in? Do colonial fantasies, for example, exist in isolation from ideas about Heimat and from the construction of regional 'fatherlands', or are there significant overlaps between these different forms of nationhood? If the cultural history of empire was to address such questions, it would not only add to our understanding of German colonialism, but also enrich other fields of historiography.

\section{Around 1970, Hans-Ulrich Wehler suggested in various works that German Weltpolitik was a strategy to divert public opinion from unresolved social tensions at home, utilizing enthusiasm for global expansion as a kind of collective displacement activity. Has the new research effectively superseded older models of German imperialism, or is it seeking to revive such models in a new guise?}

Kundrus: In his analysis of Bismarck's about-face on colonies, Hans-Ulrich Wehler emphasized the chancellor's political power strategy. 'Social imperialism' was a way of masking the German nation's internal class conflict, and of delaying real social reforms. Thus, Wehler was addressing colonialism's significance for the metropolis. Such approaches, based on the sociology of hegemony, cannot and should not be ignored by new work, as Jürgen Osterhammel and Sebastian Conrad have pointed out. But current research on colonialism goes beyond Wehler's instrumental perspective. In its heyday, imperialism was a phenomenon of global significance, and German colonialism can be viewed as a part of this European history, a history of entanglement. These interactions affected the German colonies in ways that varied from colony 
to colony and that were at times contradictory. Moreover, new approaches to the study of colonialism help to elucidate just how relevant non-European cultures were for Germany's selfperception as a culture or 'civilization'. This is another feature of recent scholarship: an attempt to grasp colonialism as a phenomenon that is global, European, and national at the same time. Such work acknowledges the special significance of colonial rule for the colonies and Germany. Moreover, Bismarck's 'moratorium' represented only one side of the political coin. Liberals such as Friedrich Naumann hoped that a successful German policy of expansion would yield the exact opposite of what the Chancellor expected, namely fundamental reforms of Germany's constitution and domestic politics.

Rüger: Important aspects of Wehler's interpretation have been revised, but not really by the literature referred to here. In fact, the cultural history of German colonialism has [End Page 254] been written mostly in isolation from the sort of questions that Wehler and others were interested in in the 1970s. The challenge remains, it seems to me, to relate these two historiographical strands to each other: the political and socio-economic history of imperialism on the one hand and the cultural history of colonialism on the other. There is perhaps one area in which the latter can be seen as commenting on the former, albeit rather implicitly. In most of the recent literature on German colonialism the main actors stem from the middle classes: scientists and explorers, writers and novelists, missionaries and campaigners. They were part of precisely the strata of German society that Eley and Blackbourn had emphasized in their revision of Wehler. For them, it was the bourgeoisie, not the traditional aristocratic elite, who were the driving force behind much of the political change after Bismarck. The cultural history of German colonialism seems to lend support to this interpretation: the imperial project now appears to have been much less run 'from above' than Wehler suggested.

Naranch: Neither of the suggested alternatives strikes me as particularly persuasive. To some extent, much of the new research has simply sidestepped the enormously complex issue of social imperialism in favour of other topics. The interest in the 1960s and 1970s in the domestic dimensions of colonialism was the result of the breakthrough of Gesellschaftsgeschichte and its successful challenge to diplomatic narratives of German imperial expansion. The social imperialist model that Wehler proposed in his pioneering research on Bismarck's colonial decision-making was followed several years later by Klaus Bade's impressive study of Friedrich Fabri and the early colonial movement. The debate over social imperialism prompted by Wehler's and Bade's research was extremely wide-ranging and insightful. African historians criticized social imperialist models for their Eurocentrism and neglect of actors in the colonial periphery. Geoff Eley proposed an appealing alternative model of social imperialism that focused on the role of nationalist pressure groups and progressive colonial reformers in shaping public opinion, not the manipulations of conservative elites. So it is important to contextualize the Wehlerian social imperialist model within a remarkably dynamic and contested historiographical landscape. One of the more encouraging recent trends in German colonial studies has been the rediscovery of political culture. The revived interest in domestic politics, class and the public sphere makes the concept of social imperialism newly relevant to the field, although the models from the past need updating to reflect the cultural historical work that has been done over the past decade. My own preliminary research in this vein focuses upon the role played by the German media, especially print journalism, in shaping public opinion on matters of colonial policy in ways that did not necessarily reflect the desires of private colonial interest 
groups or conservative political elites. One feature of social imperialist models that seems particularly important in this regard relates to the efforts by liberals and conservatives to form stable pro-colonial political majorities by marginalizing oppositional groups who questioned the necessity and feasibility of the colonial project. Such activities were waged by a professionalized cadre of colonial publicists, news reporters, and political strategists, who developed novel rhetorical strategies for supporting German colonial expansion. To counter such efforts, left liberal, Catholic, and Social Democratic critics derided colonial advocates as dangerous fanatics (Kolonialschwärmer) whose colonial agenda lacked a rational foundation. Incensed colonial spokesmen frequently responded with a highly polarized language [End Page 255] that branded their opponents not only as unpatriotic, but also as racially disloyal. Such far-reaching transformations of the Wilhelmine public sphere were a side-effect of increasingly uncivil colonial policy debates. These become visible when analysed using the methods of close textual reading and discourse analysis developed by cultural and postcolonial studies.

Zimmerer: Hans-Ulrich Wehler's concept of Sozialimperialismus, the idea that imperial adventures were used by Bismarck to divert attention from social problems at home, was a major contribution to the study of imperialism. It successfully brought imperialism back from diplomatic history and linked it to its social and political context. Wehler showed that Germany's colonial empire was indeed important for German history and indirectly acknowledged the importance of colonial dreams for large parts of German society. For only if colonial ideas were attractive to substantial parts of German society could they be used to divert public attention. Wehler's theoretical model has not lost its importance in today's world, and is neither limited to Germany nor to the nineteenth century. But Wehler's model also exemplifies the trend in German studies to see everything in relation to national history. By giving a domestic policy explanation for colonialism he embedded colonialism in the realm of German domestic politics. It is the reduction of a global phenomenon, colonialism, to petty domestic politics. Some of the new research under the heading of transnational history seems to follow the same logic. It is German national history that lends importance to events and developments. This just re-emphasizes the paradigm of the nation state. Colonialism and the colonial imagination are however global driving forces sui generis, and ought to be analysed in a global framework. This long overdue globalization of German history would truly be transnational and better help us understand the Europeanization of the globe during the last 600 years and its impact on the world and Europe today.

Berman: Social history emphasizes national history (so it is like an older political history); colonialism therefore turns out to be a mere episode, an adventure, an escape or escapism, of secondary importance. Recent postcolonial research emphasizes the encounter with the 'other' and therefore uncovers questions of desire (hence, theories of psychoanalysis and gender issues) and recognition. This postcolonialism has put the 'Id' back into 'Identity'. Might one, somewhat ironically, contrast an implicit Fichteanism in Wehler - the priority of the Ich - with a postcolonial Hegelianism, a dialectic of recognition? The latter point might be documented via Fanon: for all the trivial complaining about a politically incorrect Hegel, the master-slave drama continues to inform much of this criticism. The former point - the allegation of a Fichtean nationalism in social history - is precisely the criticism that Paul Gilroy levelled against Birmingham School 'cultural studies' long ago. There may be an ideological slippage from asserting the primacy of Innenpolitik to a valorization of Inland and a hostility towards 
Ausländer. Does even a classic title like The Making of the English Working Class imply some exclusion through the national adjective? But such implicit nationalism may have been less evident in a different conceptual era. Wehler's theory of a 'displacement'-domestic dissatisfaction exported into foreign wars — utilizes the term pejoratively: the national 'place' is naturalized as primary, colonialism is therefore a false place. In contrast, for (some) postcolonialism, the notion of 'place' is decentred from the start, hence the focus on transnational encounters, which are however by no means secondary to national [End Page 256] events. To be sure, there are also other postcolonial strands that just dogmatically expand an older naturalizing nationalism to other parts of the world. 'Germany for the Germans' becomes 'Vietnam for the Vietnamese', 'Tanzania for the Tanzanians', and make sure the foreigners leave: this leftist internationalism can universalize xenophobia. Jeder ist irgendwo Ausländerfeind.

Wildenthal: Let me distinguish two ways I see the term Sonderweg used these days: one usage is merely to mention that 'the German case is different' without seeking to explain why (because the author's goal lies elsewhere). The other usage refers more specifically to Wehler's argument - which was an even larger explanatory framework than our question indicates, for he argues for the impact of social imperialism and related politics on the totality of German society. If we work with this distinction I am making, then: yes, much newer work on German imperialism/colonialism asserts or indicates that the German case is different. No, this work does not advance an argument on the scale of Wehler's about why that difference existed or what significance that had for all of German politics and society. I don't see scholars making arguments on that ambitious scale in recent years, for good or ill. Probably the most interesting book to consider in light of this question is Isabel Hull's Absolute Destruction, which notes that the constitutional arrangement affecting the military in Germany was different and then advances an argument about a consistent and distinctive pattern of abuse of civilians and defeated combatants in successive wars that was perpetuated not by way of ideology but rather by way of technical goals and bureaucratic habits within an organization. This isn't the place for a review of this wonderfully thought-provoking book; I just want to point out a few ironies of thinking of it as a Sonderweg book in the Wehlerian sense: her argument concerns only the military, not all of German society, and she often suggests that if German civilians had been constitutionally able to interfere in military culture, they would have brought it back towards the European mainstream. Indeed, by setting for herself the goal of making her argument without reference to an expansive concept like ideology, she must limit her argument's scope to a specific institution - one can hardly argue for an organizational culture of an entire society. From the outset, she sets aside the question of why that constitutional arrangement came about and why it did not change. In the more limited sense of Sonderweg as 'different' and in the context of German colonial studies, she focuses on the genocidal war of around 1904-1907 in German Southwest Africa - a key piece of evidence for anyone arguing for the distinctiveness of German colonialism - but she does not argue that German colonial officials, settlers, and so on were different from their counterparts in other empires. Instead, Hull argues that specifically colonial practices were not responsible for the genocide; rather, the German military was, as it had already developed and acted inside Europe. Since the German Southwest African war has a special place as evidence of German colonialism being different from others, I would like to mention Andreas Eckert's brief remarks about how that war and genocide figure differently in German as opposed to African historiographies (see his essay in Völkermord in Deutsch- 
Südwestafrika, 2003). For historians of Germany, German colonial wars will probably be analysed in the context of the Holocaust rather than other colonial wars and practices in the region. Hull's book offers a strongly reasoned case for that being exactly the right approach, at least for some colonial wars. Be that as it may, that does not exhaust the possibilities for interpreting German colonialism, and placing it in [End Page 257] its African, Pacific or Asian context is still rare (see for example the work of Adjaï Oloukpona-Yinnon, Jan-Bart Gewald, Gesine Krüger, and J. A. Moses). Seeing German colonialism through those historiographies does point us in directions other than the Sonderweg thesis.

\section{The new interest in the role of the colonial 'other' in shaping modern German identity has been heavily influenced by new work on the British and French empires, for example the lively debate that has sprung up around Catherine Hall's Civilising Subjects. What can historians of German colonialism learn from these historiographies-which lessons have they taken on board, which have they ignored?}

Naranch: Because Germany's formal period of colonial rule encompassed at most two to three generations of administrative officials, military officers, missionaries, merchants, and settlers, much of the new research on German colonial discourses of self and other has focused on the postcolonial repercussions and racial legacies of the colonial encounter in Weimar, Nazi and Cold War Germany. Indeed, an important contributing impulse in the early 1990s that helped inspire new work in German colonial history was the public reaction to neo-Nazi attacks on ethnic minorities and asylum seekers in the reunified German Federal Republic. This prompted some scholars to investigate the genealogies of German racism, exclusionary citizenship laws, and xenophobia that predated National Socialism. In Civilising Subjects, Catherine Hall makes a similar rhetorical move at the start of her narrative by connecting her own interest in eighteenth and nineteenth-century British colonial history - especially post-emancipation race relations in Jamaica and Birmingham - to issues of racism and cultural diversity in contemporary Britain. The interest in German colonial history, like that in French, British, Dutch, American and other colonial histories, appears to be motivated in no small part by the debate over multiculturalism in Europe and North America. On the other hand, German historians tend to view colonial dichotomies of self and other within a more variegated categorical landscape that includes other prominent polarities: Aryan versus Semite, Catholic versus Protestant, Kultur versus civilization, Naturvolk versus Kulturvolk, and so on. One might even make the case that the boundaries of the German colonial imagination were always more permeable than those of other Western states with longer overseas colonial pedigrees. They thus could be more easily transposed onto adjacent parts of the world such as east-central Europe, and onto ethnic minorities such as Slavs and Jews between 1918 and 1945, the first postcolonial decades of modern German history.

Rüger: Catherine Hall has been influential, I think, because she demonstrated how different lines of enquiry that had previously been left unconnected could be brought together. Thus we now think of citizenship, empire, gender and race in the same context. Some of the authors working on the cultural history of German colonialism, Lora Wildenthal in particular, have taken this on board, with impressive results. Others, in contrast, have tended to favour one single category in their research. Thus some of the recent work has suggested that space, rather than race, should be the main conceptual tool for the enquiry into German imperialism. I am 
sceptical — race, to my mind, matters very much for our understanding of the Wilhelmine colonial project. [End Page 258] Partly so in the sense suggested by Pascal Grosse, who has shown that racial thought was just as important for colonial policy as ideas about space, certainly as far as the theoretical and scientific context is concerned. Yet race mattered also as a more diffuse concept, often evoked by campaigners and colonialists as synonymous with nation or culture, but also family. Surely it is the intersection of these categories that should interest us most.

Zimmerer: I very much doubt that most practitioners of the new German colonial history are really interested in the colonial other. At most they are interested in the way in which German intellectuals and writers have dealt with the phenomenon of the other. The other is often seen as a projection screen for Wilhelmine desires, wishes and imaginaries. Important as this is, it is not the same as a real interest in the other. Treating the other as a homogenous group, and situating it in an exotic surrounding, is an approach which cements the us-them binary between Germans/Europeans and non-Europeans. This is not much more than an essentialization of the other that is in danger of simply repeating colonial stereotypes. There is obviously nothing wrong with an interest in the history of the idea of the other, or with an analysis of German perception of the other in the nineteenth or twentieth centuries. In order to understand the historical reality of the other, however, different sources have to be used, notably sources produced by the others themselves. If those are not available, we ought to look at sources produced by Europeans in direct contact with non-Europeans (or whoever is seen as the other). Literary texts (including newspaper and magazine articles), as they are currently featuring highly since they are easier to access than archival material, come last on the list. The narrower use of source material seems to be the main difference to the approaches by Catherine Hall and others. In the process of recreating themselves as cultural/colonial studies, German literature studies widened their thematic reach, but not the scope of their sources.

Wildenthal: Recent work on the French and British empires has been a very beneficial influence. It does seem to have influenced the choice of topics among historians of German colonialism. Turning specifically to Catherine Hall: her œuvre has been brilliant and inspiring, regarding especially gender, class, and masculinity. Just within colonial studies, however, it still seems to me that Ann Stoler, Mary Louise Pratt or Gauri Viswanathan have had a greater impact regarding the general theme of the other shaping a European identity. Civilising Subjects promises a co-construction of identities in the British-Jamaican encounter, but as Hall herself points out in a response to reviewers, British people are very much at the centre of that account, not black Jamaicans. Carrying forward Hall's theoretical ambitions while using German materials would be richly promising. Birthe Kundrus has already shown the power of focusing on the other for an understanding of German identity in her book, which contributes to overcoming the irritatingly durable separation in the literature between German colonialism and German nationalism. Books such as Gesine Krüger's and the recent outpouring of work on Africans in Germany point toward histories of interaction and the co-construction of identities. I wish there were more accounts in which various kinds of intermediary figures in the colonies (such as translators, or mission members of African or Pacific descent) were not merely present, but rather were prominently featured speakers. Looking at Germans in colonial empires other than the German one, or at encounters such as Harry Liebersohn has analysed, would increase the source base, while of course shifting the [End Page 259] analysis somewhat. I say this 
because I find that accounts of European identity being shaped by an other can lead to the latter appearing as an undifferentiated, homogeneous mass and to the implication that their first real contact with Europeans or European ways is identified with the chronology of European expansion, whereas there had in fact been more informal contacts before.

Kundrus: Historiography on German colonialism has been heavily influenced by research on the British Empire and by US scholars working on European colonialism. Among the most influential studies were those by Ann Laura Stoler and Frederick Cooper, which foregrounded the immaterial elements of human life, such as attitudes, mentalities, and ideas, which had previously occupied little space in a scholarship focused on the history of political and social structures. The charge that, in the wake of this reorientation, the material realities and economic basis of colonialism continue to be neglected may be partially justified. Two factors that underpin this tendency are the decline of economic history in Germany, and the fact that German colonial history was characterized by much planning and declarations, even in those brief periods in which the country actually controlled colonial possessions. German scholars might be well advised to undertake more forays into comparative work on the British and French cases, and examining whether insights from colleagues' work on other colonial empires can be transferred to the German context, as Ulrike Lindner or George Steinmetz have done. Ultimately, however, all studies in colonial history face the same challenge. Edward Said summarized this fundamental heuristic problem of all colonialisms: 'The problem, then, is to keep in mind two ideas that are in many ways antithetical - the fact of the imperial divide, on the one hand, and the notion of shared experiences, on the other.' Colonialisms are always about shared and divided histories, and understanding and interpreting these structures is the common task of all historiography of the colonial past. Presumably, every national historiography - and every national politics of history - is caught up in its own mistakes: in France, for example, the positive perspective on the country's colonial past that is now set down by law; in Germany, the hesitation in formulating an official apology to the Herero or the sometimes peculiar popular representations of the country's colonial past on television that have emerged at the end of a decades-long phase of colonial amnesia.

Berman: An older paradigm wondered about the Sonderweg, contrasting the successful democratic trajectories of the West with a German history that led to National Socialism and the Holocaust. There were always objections, on the left and the right, that pointed to British and French colonialism (and to racial segregation in the US) as evidence that the Western discourse of democracy was merely rhetorical and therefore no standard by which to measure Germany. A German (and Germanist) scholarship that reduces the difference between Germany and the West might, of course, argue that, on the contrary, democratic and middle-class contents could thrive in Germany, just as in the West-but in this case, the opposite move is more typical: not only were the democracies implicated in the undemocratic practice of colonialism, Germany was just as bad, certainly during the brief period of the overseas empire but also (according to Zantop) during the empire of fantasy as well. The Sonderweg disappears through the Europeanization of colonial guilt. In other words, by making German colonialism akin to British and French colonialism, this discursive shift leads to at least two notable accomplishments. First, German history [End Page 260] becomes more like British and French history - a kind of retroactive Maastricht treaty, a minimization of national difference in the shadow of the European Union. Second, the shared European history is defined in terms of guilt — is colonial history the new 
Holocaust Studies? My point is not to open the nasty issues of competition over victimhood but to highlight the definition of history, national or European, in terms of inherited guilt - surely an enormous difference from older narratives of linear progress or even triumph. Contemporary historiographies of guilt may play the role in largely secularized cultures that Nietzsche ascribed to Christianity. Yet studies of German colonialism still miss some key questions that might be better addressed in a German context than elsewhere. There is, for example, the question of the working-class movement (so strong in Germany in the imperial era), Communism and the GDR. What were the resonances between the rhetoric of internationalism and European imperialism: from Marx on India to the transformation of 'internationalism' into Russian foreign policy? In addition, how does the structure of the Reich, its internal political organization (the Länder) as well as its European expanse (Prussia and Poland) shed light on 'Empire'? Parallel questions in France (Brittany) or England (Wales, Scotland) are not as salient (although Ireland surely is). Some of this comes up in Schmitt's constitutional theory but also in his dissection of the relationship between democracy and homogeneity. At this point, however, much more attention has to be paid to the 'imperial' structure of Austro-Hungary.

\section{Why have gender and sexuality played such an important role in new work on the colonial imagination? In what sense did white women suffer from the logic of colonial regimes, and in what sense were they, and feminist aspirations at large, implicated in the colonialist project?}

Zimmerer: The binary encoding between colonizer and colonized, European and non-European, civilized and non-civilized follows the same logic as male-female opposition. Given that this distinction translated into real discrimination against women in many societies, past and present, that women have been and still are subaltern, a conflation of the history of gender and colonialism comes as no surprise. The interest in sexuality and colonialism stems from the fact that sexual encounters are the most intimate of contacts between Europeans and non-Europeans. In principle a private affair, they allow a deeper insight into the day-to-day working of colonial society than the political or administrative dimension of colonial rule. Furthermore, colonial societies rested to no small extent on the establishment of a racial order (most radically in German Southwest Africa). For this to function, segregation between colonizer and colonized became an important issue (though not necessarily strictly enforced). Women and their ascribed roles played an important part in this. And from the very beginning, the European encounter with the colonial world was highly sexualized. The use of language indicates this: 'penetration', 'virgin land' and so on are just a few indications of an imaginary repertoire which was deeply influenced by sexualized images. Even the perception of the other, both male and female, was deeply influenced by their alleged sexual virility or promiscuity. One could write a history of Europe's mental engagement with the colonial world in terms of sexualized images.

Rüger: That gender and sexuality as key concepts in cultural history should play an important role in the new research on German colonialism is hardly surprising. The [End Page 261] enquiry into the place of women in the colonial project has been particularly productive. Lora Wildenthal and others have highlighted the conflicted nature of women's involvement. Just as empire and enlightenment (to borrow from Russell Berman) are not inherently contradictory, feminism and colonialism should not be seen as necessarily oppositional movements. Many 
women who participated in public life were enthusiastic about empire and keen to play an active part. Their motives could be informed as much by ideas about German superiority and 'civilization' as they had to do with gaining new freedoms as women. Yet, in order to carve a niche for themselves in the colonial project they often enough had to adopt traditional ideas about femininity and gender roles. It is in this contradictory way that white German women from a wide range of political and social backgrounds participated in imperial expansion. What is impressive about this new research is not only that it forces us to think about the colonial project and feminist activity in one context, but also that it connects experience and imagination with events and decisions.

Berman: Given the extensive impact of feminism and gender studies in scholarship throughout the humanities and the social sciences in recent decades, it is hardly surprising that questions of gender have been prominent in the new scholarship on colonialism. Indeed, it would be surprising, at this point, if gender questions were absent. Yet the question as to whether 'white' women (are they all the same? upper class, working class? Protestant, Catholic, Jewish? urban and rural? and so on) suffered or benefited is just too broad a brush. I suppose both answers are correct and at the same time false. The challenge to scholarship ought to be to tease out the complexities of both the experience and the discourses of race and gender (understanding that 'experience' and 'discourse' imply two distinct types of method), their overlaps and their distinctiveness. What we ought to try to avoid is a melodrama of villains and victims - and that holds for race as well as for gender. To the extent that we give priority to experience, it is probably fair to say that German colonialism - despite the presence of some women in the colonies - largely involved the emigration ('displacement') of men from Germany to Africa. The project to establish settler colonies, the establishment of a significant population of indigenous colonizers - as in Australia or Canada as well as in Algeria - never really succeeded. To evaluate the experience of this male colonization on white women either means looking at the small number of German women who really spent time in the colonies, or more abstractly trying to evaluate how women in Germany experienced the population movements of men. Of greater note, however, would be a consideration of the discourse of gender in relation to colonialism. Women colonizers wrote important memoirs and fiction (Frieda von Bülow) which contributed to the public understanding of colonialism. It is important to keep a clear understanding of what sort of question one wants to pose.

Wildenthal: For centuries now, people concerned with race have turned sooner or later in their writings or policies to sex differences and to women. Ann Stoler offered a powerful formulation of this fundamental role of gender in racial thinking, and that put it on the agenda of colonial studies. What is new since the second half of the twentieth century is the prevalence of a feminist and anti-racist standpoint. I would like to distinguish perhaps more strongly than the question suggests between gender on the one hand and (white) women on the other. Gender is now ubiquitous in work on German and other colonialisms. [End Page 262] Women as historical actors are not. What is problematic for me here is that subjecting some source material-a court case, a short story - to a quick 'gender analysis' can easily become a mechanistic enterprise with unsurprising results. It is hard to offer an interesting gender analysis in passing, because a good one tends to complicate the story further, not offer a quick answer. There is still little work on actual women on all sides of the German colonial encounter, but people don't seem to notice that because there is so much that addresses gender in some way. We know very little about German 
women's participation in antislavery movements, for example, or how missionary goals and ideas shaped the wider German society's perceptions of Africans and other colonized peoples, especially German women's perceptions. The reason I think this is so important is because I am convinced that many surprises do await those who undertake detailed empirical research on women and sexualities in German colonialism. Such surprises prevent a theoretical approach from tending toward offering canned answers. As for the second question, an answer would require more than one book, and much more than a few comments here. Work on the interpenetration of colonial regimes and feminist aspirations has been powerful within feminist studies to develop multicultural perspectives on ideas such as 'freedom'. And it has been one important pathway to the centrally important realization of how extensive and still effective the colonial shaping of our present-day world and its political vocabularies has been.

Naranch: Colonial encounters, real and imagined, brought into contact conflicting cultural attitudes regarding gender relations and sexuality. The establishment of colonial communities generated a highly variable, hybrid set of gendered discourses and unanticipated sexual practices that challenged the universality of Western notions of masculinity and femininity and prompted intense debate at home and abroad about the potential dangers for Western society of interracial sexual relationships. Examining colonial gender regimes and sexual regulations thus offers critical insights into the overall colonization process and its enduring legacy for both Western and non-Western communities involved in the colonial encounter. Colonial scholars such as Antoinette Burton, Ann Stoler, Alice Conklin, Philippa Levine, and Mrinalini Sinha have demonstrated how Victorian-era feminist agendas in the British, French, and Dutch empires reflected paternalistic Western notions of a civilizing mission of cultural uplift, sexual purity and social modernization abroad. Recent work on the German colonial women's movement has underscored the prominence of Social Darwinian and eugenicist rhetoric among Wilhelmine female colonial activists and stressed the compatibility of race thinking with the German civilizing mission. The debate over interracial sexuality in the German parliament and the attempts by colonial governors to combat racial miscegenation through marriage bans coincided with legal changes to German citizenship laws at home and led to calls to encourage the settlement of white women in the colonies. The deleterious impact on colonial race relations of the Herero and Nama Wars and the Maji Maji Uprising heightened domestic fears of sexual and racial transgression and hardened racial attitudes among both German men and women at home and in the colonies. To the extent that German feminists engaged at all in the debate over colonial reform following this devastating period of military violence, they failed to articulate an alternative vision of colonialism that differed markedly from that of their male counterparts.

[End Page 263]

Kundrus: These are three questions wrapped up in one. Colonial practices and discourse were so obviously permeated by concepts of gender - as well as concepts of race - that this aspect could not be ignored in analysis. Publications by women from the colonial era constitute a considerable proportion of the historical material available to researchers. We should, however, keep in mind that gender history is the history of men and masculinity as well, and in this area, much work remains to be done. Concerning the third question I doubt whether the goals, selfinterpretations, and worldviews that German women in the colonies and nationalist-imperialist women and their organizations in the metropoles (and what about German female missionaries?) attached to the colonial project should be described as 'feminist aspirations'. Perhaps these 
women championed their own importance and advanced their autonomy, but nonetheless embraced an ideology of difference with respect to all non-whites, non-Germans, and nonbourgeois, because of the bourgeois, nationalist, and racist logic of colonialism. Thus the question remains, if this subtle mixture of equality and difference was the norm within contemporary international feminism. Elizabeth A. Drummond's phrase 'female cultural imperialism' appears more appropriate. Instrumentalizing colonial racism to underpin and legitimize German middle and upper class women's demands for political participation went hand in hand with the loss of bourgeois promises of equality and the renunciation of universalism. This was possibly the most decisive factor that distinguished German from British 'female imperialists': German women almost completely omitted the altruistic elements which, despite their rootedness in cultural supremacy and racial difference, tempered British colonialism. The 'white woman's burden' (Antoinette Burton), as a condescending but binding responsibility to 'civilize' and support non-white women in the colonies, rarely surfaced in the German debate.

\section{The chronology of colonial acquisition and its extremely limited scope set the German case apart from British and French empire-building. However, cultural historians have suggested that the German colonial imagination closely mirrored that of the British and French, and that it rose to prominence well before, and independently of, actual colonialism. Yet British and French studies of the colonial imagination have focused on the intersection of the realms of fantasy and the reality of colonial settings. Is there a danger, therefore, that the new approach to German colonialism loses touch with concrete events, and becomes a self-referential discourse?}

Rüger: This is clearly an existing deficiency. There is a lamentable gap between the cultural and the political histories of German imperialism. The enquiry into colonial fantasies and the imperial imagination has been left sadly disconnected from the world of power and politics. What is needed is a rediscovery of the political in these cultural contexts, for two reasons. First, writing the cultural history of empire in isolation from the political context means effectively giving up the aim of explaining why and how Germany embarked on its colonial project when it did. Travel narratives and experience of space, metaphors and stereotypes of 'the other' are important if we want to understand how that 'projection surface'

(Friedrichsmeyer/Lennox/Zantop) was constituted, without which the decision for colonies cannot be adequately understood. Still, this does not explain why Bismarck believed that a certain form of empire was a good idea in the 1880s and not earlier. Second, the schism between cultural and political history can lead [End Page 264] to wrong conclusions. It might, for example, be tempting to conclude from the kind of sources that cultural historians have favoured (novels, travel writing, popular culture, film) that there was a pervasive 'imperialist imagination', a 'language of empire' or a 'culture of colonialism' in Imperial Germany. Yet it is highly doubtful whether such a consensual culture existed. Those displaying a liking for imagined imperial adventures did not have to support specific imperial policies. And even if one was to accept that a widespread disposition towards an overseas empire existed in nineteenth-century Germany, it is in no way clear what this meant politically. Do colonial fantasies lead to the acquisition of colonies? Under which circumstances and why were decisions for empire taken? The cultural history of colonialism offers few answers to such questions. 
Kundrus: In the early stages of the new research on German colonialism there were two main goals: to end the marginality of colonial history, and to demonstrate that imaginary colonialism shaped individuals' actions (even if those actions amounted to no more than a publication). It was and remains hard work to establish 'fantasies' as a genuine subject for historiography in Germany. The historic oddity of a long period of a colonialism without colonies, and the defensive academic position of colonial studies, have at times - as Lora Wildenthal, Jürgen Zimmerer and Jam Rüger argue here-produced a lack of precision when writing about the relationship between colonial discourses and practices (and the exact impact of colonial issues on German society). But perhaps it is not the overstretching of colonial imagination but the overexpansion of the colonial paradigm itself that is problematic. What was once marginalized is now overemphasized. Some studies use the concept of colonialism in an inflationary manner. There is a tendency to label nearly every illegitimate form of rule, every exotic phenomenon as 'colonial'. This is also due to the post-structuralist turn in colonial studies, as Frederick Cooper recently pointed out: "Looking for a "textual colonization" distinct from the institutions through which colonial power is exercised risks making colonialism appear everywhere-and hence nowhere.' Similar tendencies are apparent in German education studies, where challenges posed by a multicultural society of immigrants are now ascribed to the effects of postcolonialism. This leads to a loss of the discriminatory power of the term 'colonialism', and its decontextualization. Especially those practising German studies in the USA are under pressure to jump on this fashionable bandwagon, because it promises to bolster interest in a discipline in decline. I am not certain the results will be helpful.

Berman: This question prompts two responses, one methodological, the other historical and political. I will address methodology first. The anxiety expressed in the question that this scholarship might 'lose touch with concrete events, and become a self-referential discourse' is the Gretchenfrage of postmodern scholarship in general: wie hältst Du es mit der Objektivität? This is not a problem specific to historiography of German colonialism but a legacy of the decades of 'theory', the pan-textualism of Derrida and Foucault's discourse analysis. Like it or not, that theoretical burden makes questions of empirical objectivity difficult, if not impossible. This is not a function of the specific configuration of the timing of German colonialism (as suggested in the question) but a result of the 'poverty of theory', as E.P. Thompson once put it (and which, one might add, was also Faust's problem, which is where the Gretchenfrage first showed up - but that is just more literature). Turning to history and politics, let us proceed from [End Page 265] the problem of 'colonial fantasies', that is to say, the observations that (some) Germans fantasized about colonies before a (real) German colonial enterprise was underway. Zantop concludes that Germans, in the era before colonialism, were as culpable as Germanswith-colonies (per the principle: it's not the sin committed but the sinful thought that is evil). This conclusion however betrays a predisposition to find the defendant guilty. It is striking that an alternative hypothesis is not investigated: what was it in German political structures or in German cultural traditions that successfully delayed the initiation of an overseas empire? For centuries, other European states were pillaging the world, but Germany (or the German states) largely stayed out of the game. Why does postcolonial scholarship fail to see this refusal to colonize as an accomplishment rather than a failure? Probably because the underlying assumption remains one of a linear progress towards resembling the Western European state structures. 
Wildenthal: Yes, there is a danger that working on fantasy, imagination and so on can suggest a coherent discourse whose analyst need not bother with some other ideas or facts that complicate his or her account. I think I am really just saying that I disagree with a New Historicist assemblage of an 'archive' as an adequate method in German colonial studies, perhaps because we know our readers continue to be interested in the big questions that characterized the Sonderweg debate. I am upset if an author or reader draws major conclusions about the nature of German colonialism from a Nazi-era film or a Hans Grimm short story, but I am myself an eager reader of such work because it's all grist for the argument that colonialism was more influential and pervasive in German society than many historians outside the field credit. However, procolonial politics, colonial literary themes, formal empire, race, military conquest, the exotic, postcolonial encounters and so on are overlapping but certainly not coextensive concepts and phenomena. While colonialism is a truly big phenomenon, we have to refrain from inflating it into everything if it is to retain meaning. That is why I am concerned about clarity when working with eclectically assembled sources.

Naranch: Studying the development of the German colonial imagination inevitably entails an investigation of the period before formal colonization began. The German colonial imagination, however, should not be studied in isolation from the larger history of German overseas expansion. Transoceanic migration, Hanseatic commercial networks, scientific exploration, missionary activities and transnational contacts with European colonial powers and the nonWestern world all helped forge a German global imaginary that shaped in profound ways the course of German colonial history. Sebastian Conrad's recent work on globalization and nationalism in Imperial Germany takes this approach. Recent articles in German History by Frank Lorenz Müller and Matthew Fitzpatrick have also shown that the domestic debate among German liberals over Western overseas expansion during and after the 1848 Revolution involved serious discussions of colonization as a legitimate response to Germany's internal problems and as a method for protecting national interests abroad. My own research into the impact of nineteenth-century globalization upon the development of German nationalism provides further evidence that many Germans in the 1850s and 1860s were well informed about the conditions in the European colonies, in Latin America, Africa, East Asia, and the Pacific. The wide-ranging discussions in Germany and Austria concerning the [End Page 266] commercial implications of the Suez Canal for the relationship between Asian and central European markets is a case in point of how the German global imaginary was shaped by concrete events on the informal imperial periphery. As Ulrike Kirchberger and others have demonstrated, many German scientists, soldiers, merchants, and migrants lived and worked in the European colonies and transmitted their impressions of colonial life back home in the form of letters, journal articles and books. The German state did not need to be a formal colonial power in order for its citizens to experience both the fantasies and realities of colonial rule.

Zimmerer: This is indeed a danger of 'new' German colonial studies. It is certainly justified to emphasize the long engagement of parts of the German bourgeoisie with the non-European and colonial world, and this developed separately from an actual German colonial empire. To some extent the colonial discourse has become a self-referential discourse in itself. Some of the armchair colonialists, as Susan Zantop has called them, developed a colonial fantasy world, which was only loosely connected to the real colonial world, in which they lived. But this 
statement has to be amended in three important respects. First, Germans were engaged in the global European project from the very beginning. One finds them in the Spanish and Portuguese possessions as well as in British, French or Dutch. German colonialism, if not reduced to nationstate terms, is older than the foundation of German Southwest Africa in 1884. Second, some of the fantastic and utopian ideas ventilated in German colonial discourse found their way into dayto-day colonial life during the second German Reich. Third, some of the most radical colonial concepts were put into practice during World War II in the occupied Soviet Union. Understanding colonialism means studying the discourses and their translation into colonial regulations and practices.

\section{The quest for Lebensraum was a concept first popularized in Wilhelmine popular literature on colonial expansion. Can the history of German colonialism in the nineteenth- century shed new light on the assumptions underpinning Nazi foreign policy? And how does the history of German colonialism and its aftermath compare to that of other colonial latecomers, such as Italy or Japan?}

Rüger: There are obviously links between Wilhelmine and Nazi thinking about Lebensraum. Race and space were two key categories by which the German colonial project was conceptualized in the decades before 1914. The more radical of the Wilhelmine ideas about how biology explained or made necessary a certain kind of colonialism no doubt influenced Nazi thinking. Similarly, the rhetorical attraction of the Lebensraum idea that the Nazis played on can hardly be explained without referring back to the Kaiserreich. However, there are important discontinuities between Wilhelmine and Nazi thinking about Lebensraum. Geographically, the idea remained remarkably vague before 1914. There was no consensus as to where this space would be found and how it was to be gained. Because of this vagueness, but also because of a lack of political will, Lebensraum was never elevated to official policy. This is, as I found in my own research (The Great Naval Game, Cambridge, 2007), not least clear from the way in which the empire was evoked at public rituals, amongst them ceremonial troop departures, ship launches and fleet reviews. The speeches given on these occasions remained remarkably imprecise as [End Page 267] to the exact purpose of empire. 'Honour' and 'Germanness' were most frequently referred to. The troops and the warships carrying them were to represent deutsche Kultur and deutsches Wesen, Macht, Kraft and Ehre. Yet, the nature of 'overseas' and Germany's mission abroad remained unexplored, as if the projection of the kleindeutsche nation onto the sea was more important than the formulation of any concrete colonial aims or purposes. This 'secondary colonialism' (Russell Berman) stands in clear contrast to Hitler's foreign policy, which did have a stated aim of securing the Lebensraum deemed vital for Germany's future. This space, another important discontinuity, was to be found not in an overseas empire, but on the continent, particularly in eastern Europe.

Naranch: In the early twentieth century, right-wing nationalist interest groups appropriated Friedrich Ratzel's scientific theories linking population expansion to the need for colonial space as a justification for both German overseas imperialism and territorial expansion in east-central Europe. Their propagandistic use of Lebensraum is a telling example of the fateful melding of race and space in late Wilhelmine political discourse, as new research by Dennis Sweeney on the Pan-German biopolitical imagination reveals. Since the 1960s, German colonial scholars have 
attempted to connect Wilhelmine imperialism to Nazism and, most controversially, to the genocidal logic of the Holocaust. Woodruff Smith's influential study of German economic and biological imperialism, in which Ratzel's notion of Lebensraum figured prominently, argued that clear ideological continuities existed between nineteenth and twentieth-century German colonial thought. The newest and most exciting revisions to the continuity model are based on the notion of 'planes of equivalence" (as Eley has recently phrased it) between the colonial genocide in German Southwest Africa and Nazi practices in eastern Europe. The empirical challenge of connecting the dots between these various colonial moments remains a highly active site of research in German colonial studies. Focusing on the vertical dimensions of the German colonial imagination, however, should not come at the expense of investigating the horizontal linkages between German colonialism and those of states such as Japan and Italy, who also made the transition from colonial fantasy to colonial practice in the late nineteenth century. Examining commonalities in the German, Japanese, and Italian colonial imagination, during the period of high imperialism as well as during the fascist era, would be a very productive direction for German colonial studies to take and would be keeping in line with similar transnational and comparative approaches to German colonialism that Andrew Zimmerman, Deborah Neill, Ulrike Lindner, Britta Schilling and others are now pursuing.

Wildenthal: I have done very little primary research on the Nazi era, but as a teacher I have come to believe more strongly than ever that the Nazis were recyclers of a wide array of materials from the German political and cultural past. Their own originality consisted of unbounded ruthlessness. If we turn again to Hull's book, we see that her answer to our question would clearly be 'yes'. I have relied on works by Woodruff D. Smith, and more recently Pascal Grosse and Elizabeth Harvey, for my understanding of this question. To turn to the second question, there are broad commonalities and within those, fascinating differences. This became apparent to me during a 2002 workshop I co-hosted with anthropologist Mia Fuller at Berkeley, with the Italianists Giulia Barrera, Ruth Iyob, Pamela Ballinger, Krystyna von Henneberg and Alexander de Grand, along [End Page 268] with Germanists Helmut Bley, Pascal Grosse and Kristin Kopp. Some of this work is now available in English — see the edited volumes A Place in the Sun (2003) and Italian Colonialism: A Reader (2005). I am very struck by commonalities between German and Italian colonialisms such as the prominence of top-down settler schemes focusing on metropolitan women; a decolonization imposed by other colonial powers in 1919 and 1947 respectively; the myth of having been good and much-loved colonists; the extreme rarity of a German or Italian-speaking cohort of postcolonial critics from those colonial empires; the pattern of treatment of the subject of colonialism in the two national historiographies; and of course the question of how each country's colonial racism related to its fascist movement and regime. Japan's 'anticolonial imperialism' offers an interesting parallel to Germany's resentment of Britain's imperial supremacy. To bring together scholars of cultural as well as political and economic histories of these three empires to carry out a comparative project would be a wonderful idea.

Berman: The key thesis regarding a connection between nineteenth-century imperialism and National Socialism is still Arendt's Origins of Totalitarianism. It was not about some abstractly comparative brutality (of which she was of course aware); it concerned rather the assertion that European imperialism contributed to the erosion of the political category of the nation-state viewed as the primary guarantor of civil rights. The complex configuration of thought involves 
the combination of a de facto conservative anti-imperialism, which asserts that imperialism is not in the national interest, with a liberal expectation that the state guarantees the rule of law, which is the only possible framework for rights. The lawlessness of imperialism (cf. Heart of Darkness) paves the way for the perpetual extralegality of totalitarianism. (We still need the parallel demonstration for the lawlessness of Communist internationalism and its dismissiveness toward 'bourgeois' legality.) Stepping back from Arendt, one might ask whether the Bismarckian worries that colonialism might not be in German national interest sheds some light on transitions within Nazi foreign policy: at what point does a still national-interest driven foreign policy that tried to assert Germany's position within the European international order give way to a racedriven disregard for national interests and international law. For example, Mathias Küntzel shows in Dschihad und Judenhass (English translation: Jihad and Jew-Hatred, 2007) how Nazi foreign policy at first remained disengaged from the question of Zionism and the British mandate in Palestine, as long as German 'national interest' dictated a need to try to placate England. Once that effort ended, and German foreign policy underwent a radicalization, considerable steps were undertaken to fund Arab radicalism (including the Muslim Brotherhood) against British colonialism in the spirit of Nazi ideological antisemitism. One might see this transition as indicative of the shift from a national foreign policy to a racial-international agenda consistent with an Arendtian model of totalitarianism.

Kundrus: The history of colonialism can shed new light on Nazi imperialism and, in particular, Nazi modes of warfare and occupation in the East. But I would like to relativize the significance of German colonialism and stress the European dimension of imperialism. From this vantage point, the imperial world of the 1930s, especially the British Empire, was a kind of 'sounding board' for National Socialism. Furthermore, I am wary of explanatory models - for example, notions of continuity - that emphasize the way in which the German colonial experience was cemented over time. We know too [End Page 269] little about how, whether and to what extent, for example, the Wehrmacht drew on German colonial experience in developing its operative or strategic plans during World War II. Furthermore, recognizing continuities in attitudes to the use of force is a difficult undertaking, which is made no easier by changes in actors and locations. Instead, I would like to stress how the National Socialists revived, carried on, and developed what they perceived as colonial traditions. We might say that the German overseas colonies were irrelevant to Hitler's plans, but that the goals and interpretative framework in which Nazi expansion occurred were inspired by European imperialism - as part of a renewed engagement with the German imperial past and present by the Nazis. And we should not forget that historical antecedents are just as frequently revisited because one aims to cut off, rather than renew, any connection with them. Just as pre-World War I Prussian settlement in the East was considered an instructive example of how things should not be done, the Nazis regarded the actual imperial efforts of the Kaiserreich as misguided. I would also advocate examining parallels or analogies to other constellations of foreign rule. Comparing forms of colonialism and Nazi occupation in the East can uncover similarities, but it also shows the unique features of each hegemonic system. With respect to Italy and Japan and ongoing research on how colonial warfare influenced warfare in the twentieth century, it is too early to say anything substantial about what connects colonialism to 'fascism' or to brutal and unrestrained forms of warfare and occupation.

Zimmerer: Early on, postcolonial authors such as Aimé Césaire drew parallels between the Nazi occupation and extermination policies, and colonialism. The Polish Jewish lawyer Raphael 
Lemkin, who coined the term genocide and was instrumental in getting the UN Genocide Convention approved, saw in colonial rule an important precedent of Nazi policies, and Hannah Arendt discussed imperialism as an important root for totalitarianism. Until very recently, all these leads were not taken seriously by German Holocaust scholarship. This is not the place to speculate why this was the case, but the fact that with the exception of Arendt none of the authors were German, and some even non-European, probably contributed to this. Moreover, colonialism had a romantic appeal for some professional historians of Germany (this is linked to the relative neglect of colonialism in German studies). The years since the public and official acknowledgement of the first German genocide in Southwest Africa (1904-1908) have seen a slight shift in perspective, although the narrow national focus by and large still dominates the debate. As with development of research on the Holocaust (Raul Hilberg), the international debate seems more advanced than the national German one. A postcolonial perspective on Nazi policies has a lot to offer and helps us understand some of the key questions of any analysis of the Third Reich and its murderous policies. It provides deeper insights into what I have elsewhere called an archaeology of genocide. Where did the idea that an entire people could simply be 'exterminated' come from, on what discursive conditions did it rest? New research on the Holocaust has emphasized the role of experts and academics in occupation policy and mass murder. Elsewhere I have identified three trajectories on which colonial ideas and images were passed from earlier - colonial - times onto the period after World War I and especially the Third Reich: personal experiences, institutional memory and collective imagination. This offered a (post-)colonial archive from which the experts could draw. It also provided the perpetrators with the chance to justify their destructive and murderous actions with [End Page 270] reference to the universally acclaimed practices of colonization (be this an implicit or an explicit process). Since colonialism was seen as something positive, as inevitable in the progress towards modernity, and since German occupation policy in large parts resembled colonial measures, many 'ordinary Germans' (Chris Browning) became willing collaborators in this horrendous crime and many perpetrators could exonerate themselves by reference to the colonial project. They might not even have recognized that the expulsion and resettlement of Jews and Slavs, and as a last consequence their murder, breached taboos of civilization as we now understand it. This is not to claim that causal connections existed between colonial developments and the Holocaust, but rather that a closer look at colonialism helps us to understand how genocidal fantasies were developed and radicalized. 